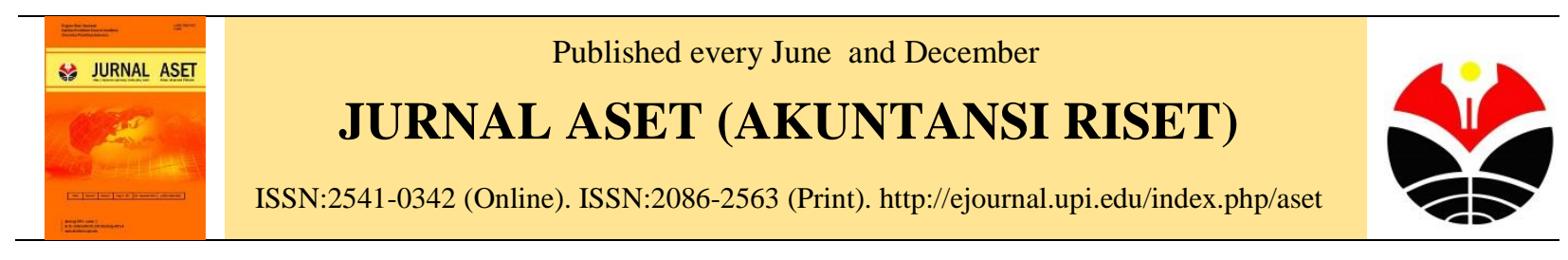

\title{
Tinjauan Atas Retribusi Daerah terhadap Pendapatan Asli Daerah Pemerintah Kota Bandung
}

\author{
Rina Tresnawati ${ }^{1}$, Erinisa Aini Putri ${ }^{2}$ \\ Program Studi Akuntansi, Fakultas Ekonomi, Universitas Widyatama, Jalan Cikutra No. \\ 204A, Bandung, Indonesia \\ rina.tresnawati@widyatama.ac.id ${ }^{1}$; erinisaputri@gmail.com²
}

\begin{abstract}
The paper aims to determine the amount of contribution from the local retribution toward Local Revenue at Bandung City in the period 2011-2015 and the criteria of effectiveness. This study uses descriptive method, which is a way to collect, arrange and classify the data so as to obtain a fairly clear picture of the problems encountered then will be drawn a conclusion the author to collect the necessary data. From result of analysis that have been processed indicate that contribution of Local Revenue of Bandung City from retribution of the average is equal to 7,30\% the rest that is equal to 93,7\% from Original Revenue Region sourced from local tax revenue, income of result of separated area wealth management As well as other income in legitimate PAD. The effectiveness level of local retribution fluctuated where in 2011 get 98,07\%, 2012 get 110,5\%, 2013 get 114,57\%, 2014 get 75,62\% and in 2015 get 60,41\%.
\end{abstract}

Keywords : Effectiveness; PAD; Retribution.

Abstrak. Penelitian ini bertujuan untuk mengetahui besarnya kontribusi retribusi daerah terhadap Pendapatan Asli Daerah Kota Bandung selama periode 2011-2015 serta kriteria efektivitasnya. Penelitian ini menggunakan metode deskriptif, yaitu suatu cara mengumpulkan, menyusun dan mengklasifikasikan data sehingga memperoleh gambaran yang cukup jelas mengenai masalah yang dihadapi, kemudian akan ditarik sebuah kesimpulan penulis melakukan pengumpulan data yang diperlukan. Dari hasil analisis yang telah diolah menunjukan bahwa kontribusi Pendapatan Asli Daerah Kota Bandung dari retribusi daerah rata-ratanya adalah sebesar 7,30\% sisanya yaitu sebesar 93,7\% dari Pendapatan Asli Daerah bersumber dari pendapatan pajak daerah, pendapatan hasil pengelolaan kekayaan daerah yang dipisahkan dan juga pendapatan lain-lain dalam PAD yang sah. Tingkat efektivitas dari retribusi daerah sendiri mengalami fluktuasi dimana tahun 2011 mendapatkan 98,07\%, 2012 mendapatkan 110,5\%, 2013 mendapatkan 114,57\%, 2014 mendapatkan 75,62\% dan pada tahun 2015 mendapatkan 60,41\%.

Kata Kunci : Efektivitas; PAD; Retribusi Daerah.

Corresponding author. rina.tresnawati@widyatama.ac.id ; erinisaputri@gmail.com

How to cite this article. Tresnawati, Putri. Tinjauan Atas Retribusi Daerah terhadap Pendapatan Asli Daerah Pemerintah Kota Bandung. Jurnal Akuntansi Riset. Program Studi Akuntansi. Fakultas Pendidikan Ekonomi dan Bisnis Universitas Pendidikan Indonesia, 9 (2), 73-80

History of article. Received: September 2017, Revision: November 2017, Published: Desember 2017 


\section{PENDAHULUAN}

\section{Latar Belakang Penelitian}

Salah satu wujud kepemerintahan yang baik ialah suatu pemerintahan yang memperhatikan dan responsif terhadap kehendak dan aspirasi masyarakat serta melibatkan daerah tersebut dalam setiap pengambilan keputusan yang menyangkut berbagai aspek kepentingan masyarakat. Masyarakat dilibatkan dan berpartisipasi dalam penyusunan program pembangunan serta pengambilan kebijakan. Selain itu manajemen kepemerintahan dilaksanakan secara terbuka dan transparan, serta dapat dipertanggungjawabkan kepada, masyarakat menggunakan prinsip-prinsip pelayanan untuk kepuasan masyarakat, efisiensi, dan efektivitas. Selama masa orde baru, harapan yang besar dari pemerintah daerah untuk dapat membangun daerah berdasarkan kemampuan dan kehendak daerah sendiri. Tetapi yang terjadi adalah ketergantungan fiskal dan subsidi serta bantuan pemerintah pusat sebagai wujud ketidak berdayaan dari Pendapatan Asli Daerah dalam membiayai belanja daerah. Beberapa komponen Pendapatan Asli Daerah (PAD) adalah pajak daerah, retribusi daerah, hasil pengelolaan kekayaan daerah yang dipisahkan, dan lain-lain PAD yang sah. Empat komponen sumber PAD tersebut khususnya pajak daerah dan retribusi daerah diharapkan dapat memberikan kontribusi yang positif dan untuk peningkatan PAD. Sumber penerimaan daerah Kota Bandung yang sudah dikembangkan salah satunya adalah penerimaan retribusi. Dimana retribusi merupakan harga dan suatu pelayanan langsung dari pemerintah daerah yang digunakan untuk menyediakan banyak tempat di kota Bandung. Beberapa tahun ini kota Bandung sudah mengalami banyak perubahan terhadap sarana dan prasarana, dimana hal tersebut bisa ditetapkan sebagai kemajuan dari Pendapatan Asli Daerah, akan tetapi dibalik hal tersebut terlihat dalam lima tahun terakhir pendapatan retribusi daerah masih mengalami naik turun pada saat realisasi. Oleh karena itu penulis tertarik untuk meneliti "Tinjauan atas Retribusi Daerah terhadap Pendapatan Asli Daerah pada Pemerintah Kota Bandung."

\section{Identifikasi Masalah}

1. Berapakah besar kontribusi retribusi sebagai sumber Pendapatan Asli Daerah Kota Bandung.

2. Bagaimana tingkat efektivitas penerimaan retribusi Kota Bandung.

\section{KAJIAN LITERATUR Pendapatan Asli Daerah}

Pengertian Pendapatan Asli Daerah berdasarkan Undang-Undang Nomor 28 Tahun 2009 yaitu sumber keuangan daerah yang digali dari wilayah daerah yang bersangkutan yang terdiri dari hasil pajak daerah, hasil retribusi daerah, hasil pengelolaan kekayaan daerah yang dipisahkan dan lain-lain pendapatan asli daerah yang sah. Menurut Halim (2004:94) menyebutkan pengertian pendapatan asli daerah yaitu penerimaan yang diperoleh dari sumber-sumber dalam wilayahnya sendiri yang dipungut berdasarkan peraturan daerah sesuai dengan peraturan perundang-undangan yang berlaku. Menurut Undang-undang Nomor 33 Tahun 2004 tentang Perimbangan Keuangan antara Pusat dan Daerah pasal 1 angka 18 menyebutkan pengertian pendapatan asli daerah yaitu pendapatan yang diperoleh dari daerah yang dipungut berdasarkan peraturan daerah sesuai dengan peraturan perundangundangan. Sedangkan menurut Widiartini (2014:28) menyebutkan pengertian pendapatan asli daerah yaitu merupakan pendapatan yang bersumber dari hasil pajak daerah, hasil retribusi daerah, hasil daerah lain yang sah, yang bertujuan untuk memberikan keleluasaan kepada daerah dalam menggali pendanaan dalam pelaksanaan otonomi daerah sebagai perwujudan asas desentralisasi. 


\section{Retribusi Daerah}

Menurut Siahaan (2010:616) menyebutkan bahwa pengertian retribusi adalah pungutan daerah sebagai pembayaran atas jasa atau pemberian izin tertentu yang khusus disediakan dan atau diberikan oleh pemerintah daerah untuk kepentingan orang pribadi atau badan. Menurut Munawir (2011:85) menyebutkan bahwa pengertian retribusi adalah iuran kepada pemerintah yang dapat dipaksakan dan dapat jasa balik secara langsung dapat ditunjuk. Paksaan disini yakni bersifat ekonomis karena siapa saja yang tidak merasakan jasa balik dari pemerintah, tidak dikenakan iuran. Undang-Undang Nomor 28 Tahun 2009 pasal 1 ayat 10 tentang Pajak Daerah dan Retribusi Daerah menyebutkan bahwa retribusi daerah adalah pungutan daerah sebagai pembayaran atas jasa atau pemberian izin tertentu yang khusus disediakan dan/atau diberikan oleh pemerintah daerah untuk kepentingan orang pribadi atau badan."

\section{Kontribusi Retribusi}

\section{Tabel 2.1 Klasifikasi Kriteria Kontribusi Persentase Retribusi Daerah}

\begin{tabular}{cc}
\hline Persentase & Kriteria \\
\hline $0 \%-10 \%$ & Sangat Kurang \\
$10 \%-20 \%$ & Kurang \\
$20 \%-30 \%$ & Sedang \\
$30 \%-40 \%$ & Cukup Baik \\
$40 \%-50 \%$ & Baik \\
$\geq 50 \%$ & Sangat Baik \\
\hline
\end{tabular}

Sumber : Kepmendagri No.690.900.327 Tahun 1996

Efektivitas

Menurut Mardiasmo (2009:232), menggambarkan tingkat pencapaian hasil program dengan target yang ditetapkan. Secara sederhana efektivitas merupakan perbandingan outcome (hasil) dengan output (target). Menurut Halim (2008:93), rumus perhitungan rasio efektivitas adalah sebagai berikut :
Menghitung kontribusi dilakukan dengan membandingkan penerimaan retribusi daerah periode tertentu dengan penerimaan Pendapatan Asli Daerah (PAD) periode tertentu pula. Semakin besar hasilnya berarti semakin besar pula peranan retribusi daerah terhadap Pendapatan Asli Daerah, begitu pula sebaliknya jika hasil perbandingannya terlalu kecil berarti peranan retribusi daerah terhadap Pendapatan Asli Daerah (PAD) juga kecil. Menurut Mahmudi (2005) untuk mengukur kontribusi dapat dihitung dengan :

Kontribusi PAD

$$
=\frac{\text { Kontribusi Retribusi }}{\times 100 \%}
$$

Untuk mengetahui sejauh mana dana bagi hasil retribusi dalam memberikan kontribusi. Maka dikategorikan baik apabila rasio yang dicapai minimal $50 \%$. Untuk mengukur nilai kontribusi secara lebih rinci digunakan kriteria kontribusi ke dalam enam tingkat kontribusi sebagai berikut : Sangat Baik

Rasio Efektivitas $=\frac{\text { Realisasi }}{\text { Target }} \times 100 \%$ Halim (2008:93) menyatakan bahwa dalam perhitungan efektivitas apabila yang dicapai minimal satu atau 100\% maka rasio efektivitas semakin baik artinya semakin efektif. Demikian pula sebaliknya, semakin kecil persentase efektivitasnya semakin tidak efektif. Kriteria yang digunakan untuk menilai efektivitas pemungutan pajak atau 
retribusi secara lebih rinci digunakan

kriteria kepemendagri No.690.900.327
Tahun 1996 tentang Pedoman Penilaian

Kriteria Efektivitas sebagai berikut :

Tabel 2.2 Klasifikasi Kriteria Nilai Efektivitas Retribusi Daerah

\begin{tabular}{cc}
\hline Persentase & Kriteria \\
\hline$>100 \%$ & Sangat Efektif \\
$90-100 \%$ & Efektif \\
$80-90 \%$ & Cukup Efektif \\
$60-80 \%$ & Kurang Efektif \\
$<60 \%$ & Tidak Efektif \\
\hline
\end{tabular}

Sumber : Kepmendagri No.690.900.327 Tahun 1996

\section{METODE PENELITIAN}

Metode penelitian ini menggunakan metode deskriptif. Menurut Sugiyono (2005: 21) pengertian metode deskriptif adalah metode yang digunakan untuk menggambarkan atau menganalisis suatu hasil penelitian. Oleh karena itu penulis menggunakan metode deskriptif untuk menggambarkan dan menggunakan data yang telah diperoleh pada lokasi tinjauan untuk mengetahui seberapa besar kontribusi pendapatan retribusi daerah dan tingkat efektivitasnya pada PAD, dan kemudian membuat kesimpulan.
HASIL DAN PEMBAHASAN

Perhitungan Kontribusi Retribusi Sebagai Sumber Pendapatan Asli Daerah Kota Bandung

Setelah berlakunya Undang-Undang Nomor 32 Tahun 2004 tentang Pemerintahan Daerah dan Undang-Undang Nomor 33 Tahun 2004 tentang Perimbangan Keuangan antara Pemerintah pusat dan Daerah, kota Bandung sudah mulai mengatur daerahnya sendiri termasuk dalam masalah keuangannya. Untuk mengetahui seberapa besar penerimaan daerah yang berasal dari retribusi daerah, berikut ini data yang diambil dari tahun 2011-2015 pada tabel 4.1 dan 4.2 :

Tabel 4.1 Rekapitulasi Target dan Realisasi Retribusi Daerah Kota Bandung

\begin{tabular}{ccc}
\hline Tahun & Target Retribusi & Realisasi Retribusi \\
\hline 2011 & 73.090 .784 .230 & 71.684 .532 .455 \\
2012 & 71.174 .028 .328 & 78.649 .880 .372 \\
2013 & 100.816 .228 .425 & 115.508 .351 .284 \\
2014 & 131.157 .749 .867 & 99.192 .319 .387 \\
2015 & 107.563 .238 .797 & 64.985 .847 .830 \\
\hline
\end{tabular}

Sumber : Dinas Pengelola Keuangan Dan Aset Daerah (DPKAD) Kota Bandung

Dari tabel 4.1 diatas dapat dilihat realisasi dan target penerimaan retribusi daerah mengalami fluktuasi dari tahun ke tahun. Pada tahun 2011 target retribusi daerah mencapai Rp73.090.784.230, tahun 2012 target retribusi mengalami penurunan menjadi Rp71.174.028.328, tahun 2013 dan 2014 target retribusi naik berturutturut menjadi Rp100.816.228.425, dan
Rp131.157.749.867, dan tahun 2015 target retribusi mengalami penurunan kembali menjadi Rp107.563.238.797. Sedangkan pada realisasinya tahun 2011 mencapai Rp71.684.532.455, pada tahun 2012 dan 2013 naik berturut-turut menjadi Rp78.649.880.372 dan Rp115.508.351.284 lalu di tahun 2014 dan 2015 turun menjadi Rp99.192.319.387 dan Rp64.985.847.830 . 


\section{Tabel 4.2 Rekapitulasi Realisasi Retribusi Daerah dan Pendapatan Asli Daerah Kota Bandung}

\begin{tabular}{lll}
\hline Tahun & Kontribusi Retribusi & Pendapatan Asli Daerah \\
\hline 2011 & 71.684 .532 .455 & 1.716 .057 .298 .378 \\
2012 & 78.649 .880 .372 & 1.442 .775 .238 .323 \\
2013 & 115.508 .351 .284 & 1.005 .583 .424 .429 \\
2014 & 99.192 .319 .387 & 833.254 .175 .288 \\
2015 & 64.985 .847 .830 & 1.859 .694 .643 .505 \\
\hline
\end{tabular}

Sumber : Dinas Pengelola Keuangan Dan Aset Daerah (DPKAD) Kota Bandung

Dari tabel 4.2 diatas dapat dilihat realisasi PAD tahun 2011 mencapai Rp1.716.057.298.37, tahun 2012 sampai dengan tahun 2014 mengalami penurunan yaitu sebesar Rp1.442.775.238.323, Rp1.005.583.424.429 dan Rp833.254.175.288, dan pada tahun 2015 naik menjadi Rp1.859.694.643.505. Berdasarkan uraian tersebut penerimaan retribusi di Kota Bandung dalam jangka waktu 5 tahun antara tahun 2011-2015 mengalami fluktuasi. Dalam hal ini dengan penerimaan retribusi daerah yang berfluktuasi dapat mempengaruhi Pendapatan Asli Daerah (PAD) di Kota Bandung. Langkah untuk mengetahui berapa kontribusi retribusi daerah dalam Pendapatan Asli Daerah yaitu :

$$
\begin{aligned}
& \text { Kontribusi PAD } \\
& =\frac{\text { Kontribusi Retribusi }}{\text { PAD }} \times 100 \%
\end{aligned}
$$

Sumber : DPKAD Kota Bandung

Dimana hasil pertahunnya adalah :

$$
\begin{aligned}
\text { Tahun } 2011= & \frac{71.684 .532 .455}{1.716 .057 .298 .378} \\
& \times 100 \%=4,17 \% \\
\text { Tahun } 2012= & \frac{78.649 .880 .372}{1.442 .775 .238 .323} \\
& \times 100 \%=5,45 \% \\
\text { Tahun } 2013= & \frac{115.508 .351 .284}{1.005 .583 .424 .429} \\
& \times 100 \%=11,48 \% \\
\text { Tahun } 2014= & \frac{99.192 .319 .387}{833.254 .175 .288} \\
& \times 100 \%=11,90 \% \\
\text { Tahun } 2015= & \frac{64.985 .847 .830}{1.859 .694 .643 .505} \\
& \times 100 \%=3,49 \%
\end{aligned}
$$

\begin{tabular}{|c|c|c|}
\hline Tahun & Kontribusi & Kriteria \\
\hline 2011 & $4,17 \%$ & Sangat Kurang \\
\hline 2012 & $5,45 \%$ & Sangat Kurang \\
\hline 2013 & $11,48 \%$ & Kurang \\
\hline 2014 & $11,90 \%$ & Kurang \\
\hline 2015 & $3,49 \%$ & Sangat Kurang \\
\hline Rata-Rata & $7,30 \%$ & Sangat Kurang \\
\hline Sumber : data diolah kembali & & $\begin{array}{l}\text { mengumpulkan retribusi daerah sesuai } \\
\text { dengan jumlah penerimaan retribusi daerah }\end{array}$ \\
\hline $\begin{array}{l}\text { Tingkat Efektivitas } \\
\text { Retribusi } \\
\text { Efektivitas retribusi daerah } \\
\text { kemampuan pemerintahan }\end{array}$ & $\begin{array}{l}\text { Penerimaan } \\
\text { menunjukkan } \\
\text { laerah dalam }\end{array}$ & $\begin{array}{l}\text { yang ditargetkan. Efektivitas retribusi } \\
\text { daerah merupakan perbandingan antara } \\
\text { realisasi dan target penerimaan retribusi } \\
\text { daerah, sehingga dapat digunakan sebagai }\end{array}$ \\
\hline
\end{tabular}

Tabel 4.3 Kontribusi Retribusi Daerah Terhadap Pendapatan Asli

\section{Daerah}


ukuran keberhasilan dalam melakukan pungutan. Berikut ini adalah rumus untuk efektivitas retribusi daerah :

Rasio Efektivitas $=\frac{\text { Realisasi }}{\text { Target }} \times 100 \%$

Sumber : Bapenda Kota Bandung

Tabel 4.4 Efektivitas Retribusi Daerah Kota Bandung

\begin{tabular}{ccccc}
\hline Tahun & Target & Realisasi & $\begin{array}{c}\text { Persentase } \\
\text { Efektivitas }\end{array}$ & $\begin{array}{c}\text { Tingkat } \\
\text { Efektivitas }\end{array}$ \\
\hline 2011 & 73.090 .784 .230 & 71.684 .532 .455 & $98,07 \%$ & Efektif \\
2012 & 71.174 .028 .328 & 78.649 .880 .372 & $110,50 \%$ & Sangat Efektif \\
2013 & 100.816 .228 .425 & 115.508 .351 .284 & $114,57 \%$ & Sangat Efektif \\
2014 & 131.157 .749 .867 & 99.192 .319 .387 & $75,62 \%$ & Kurang Efektif \\
2015 & 107.563 .238 .797 & 64.985 .847 .830 & $60,41 \%$ & Kurang Efektif \\
& & Rata-Rata & $91,83 \%$ & Efektif \\
\hline
\end{tabular}

\section{SIMPULAN DAN SARAN \\ Simpulan}

Berdasarkan hasil tinjauan atas retribusi daerah terhadap Pendapatan Asli Daerah pemerintah kota Bandung, maka penulis memberikan kesimpulan sebagi berikut: (1) Dalam lima tahun (2011-2015) retribusi kota Bandung mengalami fluktuasi target dan penurunan realisasi pada 2014-2015, meskipun seperti itu berbeda dengan pengaruhnya terhadap Pendapatan Asli Daerah yang ternyata mengalami penurunan pada tahun kelima dimana tahun 2011 sampai tahun 2014 naik berturut-turut yaitu sebesar $4,17 \%$, $5,45 \%, 11,48 \%, 11,90 \%$, tetapi mengalami penurunan yang sangat pesat pada tahun 2015 yang hanya mendapatkan 3,49\% saja. Dalam lima tahun pengaruh retribusi terhadap Pendapatan Asli Daerah mendapatkan rata-rata $7,30 \%$ dari $100 \%$ Pendapatan Asli Daerah yang didapat. Hal ini membuktikan bahwa $92,7 \%$ dari Pendapatan Asli Daerah yang didapat berasal dari pendapatan pajak daerah, pendapatan hasil pengelolaan kekayaan daerah yang dipisahkan, dan juga Pendapatan Asli Daerah dari lain-lain yang sah. Dan juga kita bisa melihat bukan karena retribusi daerah mengalami fluktuasi target dan penurunan realisasi pada 2014-2015 akan terjadi hal yang sama pada pengaruh terhadap Pendapatan Asli Daerah yang hanya mengalami penurunan pada tahun 2015 saja. (2) Dilihat dari target dan realisasi retribusi daerah kota Bandung efektivitas retribusi pada tahun 2011 termasuk dalam kriteria efektif, pada tahun 2012-2013 termasuk dalam kriteria sangat efektif, dan tahun 2014-2015 termasuk dalam kriteria tidak efektif, meskipun mengalami fluktuasi dalam lima tahun (2011-2015) retribusi daerah termasuk dalam kriteria efektif.

\section{Saran}

Dari hasil pembahasan yang telah dilakukan penulis atas tinjauan retribusi daerah terhadap Pendapatan Asli Daerah pemerintah kota Bandung, maka penulis memberikan beberapa saran yaitu :

(1) Bagi Instansi Terkait. Pemerintah harus melakukan peninjauan lebih lanjut tentang retribusi daerah dimulai dari sistem, pekerja, dan juga mengajak warga daerah untuk lebih sadar dengan adanya retribusi agar penerimaan yang didapat bisa terus dilaksanakan dengan baik, meskipun pembangunan kota Bandung sudah banyak mengalami kemajuan tetapi tetap saja penerimaan retribusi juga suatu hal yang penting untuk kemajuan daerah kota Bandung yang mungkin kedepannya menjadi daerah untuk penerapan retribusi terbaik. (2) Bagi Peneliti Selanjutnya. Bagi peneliti selanjutnya diharapkan dapat meneliti retribusi untuk tahun-tahun kedepannya secara teliti, dapat 
memberitahukan retribusi secara spesifik seperti mengetahui tarif retribusi dari beberapa Dinas yang berada di Kota Bandung, serta dapat memperbandingkan pengaruh dan efektivitas antara retribusi Kota Bandung dan retribusi dari luar Kota Bandung.

\section{REFERENSI}

\section{Buku}

Bratakusumah, S. Deddy, Solihin, Dadang. 2001. Otonomi penyelenggaraan pemerintah daerah. Jakarta : Gramedia Pustaka Utama.

Dr. Abuyamin, Oyok. 2012. Perpajakan pusat dan daerah. Edisi kedua Bandung : Humaniora

Halim, Abdul. 2004. Akuntansi Keuangan Daerah. Jakarta : Salemba Empat.

Susantih, Heny, Saftiana, Yulia. 2010. Perbandingan Indikator akinerja Keuangan Pemerintah Propinsi se Sumatra Bagian Selatan. Jurnal Simpoisium Nasional Akuntansi XII Ikatan Akuntansi Indonesia.

Kaho, Josef Riwu. 2005. Prospek Otonomi Daerah di Negara Republik Indonesia : Identifikasi FaktorFaktor yang Mempengaruhi Penyelenggaraan Otonomi Daerah. Jakatra : PT.Raja Grafindo Persada.

Mardiasmo. 2009. Akuntansi Sektor Publik. Yogyakarta : ANDI.

Munawir. 2011. Analisis Laporan Keuangan. Edisi kesebelas. Yogyakarta : Liberti.

Natia. 2014, Field Research (Studi Lapangan), Jakarta.

Siahaan, P. Marihot. 2010. Pajak Daerah dan Retribusi Daerah. Jakarta : PT.Rajagrafindo Persada.

Soelarno, Slamet. 2000. Pajak Daerah dan Retribusi Daerah. Jakarta : Aksara
Widiartini, Ketut. 2014. Otonomi Daerah. Bali : Universitas Pendidikan Ganesha.

Yani, Ahmad. 2002. Hubungan Keuangan Antara Pemerintah Pusat dan Daerah di Indonesia. Jakarta : Raja Grafindo Persada.

\section{Undang-Undang}

Kepermendagri Nomor 690.900 .327 Tahun 1996 Tentang Pedoman Penilaian Kriteria Efektivitas

Peraturan Daerah Kota Bandung Nomor 16 Tahun 2012 Tentang Penyelenggaraan Perhubungan dan Retribusi di Bidang Perhubungan

Peraturan Pemerintah Nomor 58 Tahun 2005 Tentang Pengelolaan Keuangan Daerah

Peraturan Pemerintah 66 Tahun 2001 Tentang Retribusi Daerah

Undang-Undang Nomor 28 Tahun 2009 Tentang Pajak Daerah dan Retribusi Daerah

Undang-Undang Nomor 32 Tahun 2004 Tentang Pemerintahan Daerah (Pengganti Undang-Undang Nomor 22 Tahun 1999)

Undang-Undang Nomor 33 Tahun 2004 Tentang Perimbangan Keuangan antara Pemerintah Pusat dan Daerah (Pengganti UndangUndang Nomor 25 Tahun 1999)

Undang-Undang Nomor 34 Tahun 2000 Tentang Pajak dan Retribusi Daerah (Pengganti UndangUndang Nomor 18 Tahun 1997)
Alamat website :
dishub.bandung.go.id
www.pubinfo.id
www.dpkadbandung.info 
RINA TRESNAWATI dan ERINISA AINI PUTRI / Tinjauan Retribusi Daerah Terhadap Pendapatan Asli Daerah Pemerintah Kota Bandung 